Lidija Tavčar

\title{
Razglednice Melite Rojic $v$ arhivu Narodne galerije
}

Ključne besede: likovne ustvarjalke, akademsko društvo Vesna, biografija, akvarel, razglednice, korespondenca, slovanofilstvo, etnološka kulturna dediščina

DOI: 10.4312 /ars.8.2.199-227

$\mathrm{V}$ večnacionalni avstro-ogrski monarhični tvorbi so se v drugi polovici 19. stoletja stopnjevali mednacionalni konflikti. $\mathrm{Na}$ prehodu stoletij $\mathrm{z}$ nastopom vesnanov je geslo iz naroda za narod dokončno prišlo do izraza. Med pripadniki akademskega društva Vesna je bilo poudarjeno slovanofilstvo (Simonišek, 2011, 36), ki ga prepoznamo v njihovih likovnih delih v izražanju narodne identitete, zato se zdi umestno, da je tudi slovanofilski Slovan objavljal reprodukcije slovanskih likovnih umetnikov, med njimi tudi akvarele Melite Rojic (1879-1924), ki je živela in ustvarjala v nacionalno pestri Gorici (glej prilogo 1). Kot je mogoče razbrati, pisci pri tej slikarki doslej niso dovolj poudarili njenega članstva v Vesni, ker pa se je Goričanka soočala $\mathrm{z}$ mednacionalnimi trenji, ji je po našem mnenju program Vesne ustrezal tako po nazorski kot ustvarjalni plati. Takratni urednik Slovana Fran Ilešič (1871-1941), s katerim si je slikarka dopisovala, je bil tudi predsednik Matice slovenske (1907-1914). Za čim tesnejšo zvezo s Hrvaško matico si je prizadeval tudi tako, da bi obe skupno ali vsaka zase objavljali hrvaške oziroma slovenske knjige. Še več (Šlebinger, 1928, 360-361): »Znanstveno in javno delovanje mu je v pretežni meri služilo za propagando novega ilirizma, popolnega edinstva Slovencev in Hrvatov, pri katerem bi en vrhovni knjižni jezik nastajal in nastal sam na sebi brez težkega nasilstva. $\ll^{1}$ Morda je prav on spodbudil slikarko, da je pričela razmišljati o objavah svojih akvarelov ne le v Slovanu, temveč tudi v hrvaški mesečni knjižni reviji Savremenik. Nekatere v Slovanu objavljene akvarele je Melita Rojic pozneje izdala na razglednicah, kar posredno govori, da je uresničila eno od nalog društva Vesna. Ključni uspeh vesnanov je namreč, da jim je svoje umetniške vizije uspelo predstaviti množicam s plakati, razglednicami in vabili (Simonišek, 2011, 37; prim. Narodna galerija, Fond D, Šantel, Pismo Saše Šantla eni izmed sester, Dunaj, 3. december 1903). S podatki, omenjenimi v korespondenci Melite Rojic, zlasti z njenim na novo odkritim lastnoročno zapisanim življenjepisom, se odstirajo njena poznanstva

1 Prim. Dolinar, 1990, 105: »Verjel je v nujnost jezikovno-kulturnega zbližanja in postopne združitve Slovencev z drugimi jsl. narodi ter si za to prizadeval s publicističnim in organizacijskim delom, kar je v slov. javnosti nekajkrat izzvalo polemične ugovore.« 
s sodobniki, kar omogoči, da jo z večjo gotovostjo zasidramo v čas, hkrati pa jo spoznamo kot podjetno gospo, ki je želela promovirati svoje akvarele.

V poznih 50. letih 20. stoletja Karel Dobida (1896-1964) očitno ni poznal niti slikarkine korespondence niti njenega življenjepisa, zato je preko na novo zakoličene državne meje iskal stike s slikarkino sestrično Pavlo Makuc. Ta mu je sporočila spomine na sorodnico, tako da je lahko Dobida na njihovi podlagi Meliti Rojic posvetil verodostojno leksikalno geslo. Drobci iz slikarkine in Dobidove korespondence prinašajo nova vedenja o slikarki in njenem opusu.

\section{Korespondenca Melite Rojic z urednikom Slovana Franom Ilešičem}

$\mathrm{V}$ rokopisnem oddelku NUK-a hranijo skupaj sedem pisem, dopisnic in razglednico, ki jih je Melita Rojic naslovila na urednika Slovana Frana Ilešiča; v enem od njih je med drugim zapisala tudi kratek življenjepis. Ker je dragocen dokument, njeno pismo objavljamo v celoti:

\section{Velecenjeni gospod urednik!}

Blagovolite sprejeti v naznanje, da sem $z$ današnjim dnem odposlala obljubljene akvarele na izbiro za Vaš cenj. List "Slovan", ako bi jih rabili, kar bi me jako veselilo. Sicer pa prosim, naj se pazi, da se ne pokvarijo, in da se mi iste po odrabi takoj vrnejo, ako bi jih Vi, gosp. Doktor, ne poslali tudi »Savremeniku« $v$ pogled $z$ enakimi opazkami.

Kar se zadeva moje malenkosti, utegne Vam biti, cenj. Gospod urednik znano, da sem roj. Goričanka, hčerka v obče spoštovanega, na Goriškem jako priljubljenega zdravnika ter bivšega, dolgoletnega, slovenskega poslanca itd. dr. Aleksija Rafaela Rojica iz Gorice. Morda bi utegnilo zanimati "Savremenik" dejstvo, da je moja mati bila $v$ sorodu s slavnoznanim hrvaškim pesnikom, polkovnikom Ivanom vitezom Trnsky. ${ }^{2}$ Že v otroški dobi sem bila navdušena za slikarstvo in glasbo. Izprva sem se posvetila izključno glasbi, pozneje pa se je pojavilo $v$ meni čedalje veselje do slikarstva, zlasti do akvarela, kateremu sem se pozneje povsem posvetila in kateremu ostanem tudi $v$ bodoče zvesta. - Učili sta me izvrstni in znani umetnici, učenki monakovske in budimpeštanske slikarske akademije ter še različnih drugih slavnih slik. mojstrov.

2 Ivan Trnski (1819-1910) je bil pesnik, novelist in prevajalec, ki se je formiral v času ilirizma. Deloval je v širokem časovnem obdobju od narodnega preporoda pa do obdobja, ko so se razplamteli boji med starimi in mladimi v hrvaški literaturi. Slavili so ga v času ilirizma, tedaj je bil vzor mladim, ki so v njem videli borca za narodne pravice (Vrišer, 1971, 371). Bil je sodelavec različnih časopisov, tudi Savremenika. 
Mnogo sem pridobila pa tudi resno umetniško samoobrazbo, opazovanjem narave, ponovnim potovanjem, itd. Moja dela so bila že na mnogih razstavah, n. pr. trikrat na Dunaju, nadalje v Monakovem, v Karelsruhe, Mannheimu, v mestu Sredec, ${ }^{3}$ Belgrad itd. ${ }^{4} Z$ navedenimi vrsticami sem označila Vam, cenj. Gospod urednik onemu "Savremeniku« nekaj podatkov iz svoje biografije. Vljudno prosim, da jih predelate po svoje $v$ primerno in poljudno obliko vsekakor pa tako - da se ne bo zdelo, da sem to jaz narekovala.

Prosim tudi, da uporabite od tega kar sem Vam jaz tukaj napisala samo to, kar se Vam bo primerno zdelo. Od svoje strani pa napišite, kakor bo Vam ugajalo. Nadalje želim, da obvestite »Savremenik«da pričakujem tudi od njega gratis po dva izvoda onih številk, v katerih izide moj životopis ali katera mojih slik, kakor se godi to pri »Slovanu«.

Z odličnim spoštovanjem, udana Melita Rojic. V Gorici, 4. 3.913

P. S: Ako se Vam zdi potrebno prosim pošljite priloženi oglednici-odgovarjajoči poslanim klišejem - uredništvu »Savremenika« (Melita Rojic, MS 1492, mapa $82 ; 7,1913-1914)$.

Če komentiramo delček slikarkinega pisma, se zastavi tehtno vprašanje, zakaj Melita Rojic ni poimensko navedla obeh svojih učiteljic, in sicer Avguste Šantel st. (1852-1935) in njene hčerke Henrike Šantel (1874-1940). Eden od možnih odgovorov je, da sta bili učiteljici širšemu prostoru manj znani. Ker pa je Melita podkovanost v slikanju želela poudariti, ju je »skrila" za instituciji, v katerih sta se njeni učiteljici izobraževali.

\section{Korespondenca med Karlom Dobido in Pavlo Makuc o slikarki Meliti Rojic (1879-1924)}

Karel Dobida je med obema vojnama v reviji Mladika ${ }^{5}$ (Smrekar, 2006, b. p.) objavljal članke o umetnicah in zbiranje podatkov o njih nadaljeval tudi pozneje kot ravnatelj Narodne galerije, o čemer priča ohranjena korespondenca. Leta 1958 je ob poizvedbah o goriški slikarki Meliti Rojic najprej navezal stik s Študijsko knjižnico Nova Gorica, nato pa si je dopisoval s slikarkino sestrično, učiteljico Pavlo Makuc (Arhiv Narodne galerije, 17. marec 1958, št. 79/2; 14. maj 1958, št. 79/3), ki jo je

3 Avtor članka v Slovanu (Artist, 1906/1907, 51-52) v slovenskem oddelku med slikarkami in slikarji ne navaja Melite Rojic.

4 Nabor do sedaj znanih razstav se je z njenim navajanjem tako razširil ne samo na avstro-ogrska razstavišča, temveč tudi na nemška, bolgarsko in srbsko.

5 Avtor v razstavnem katalogu o Dobidovih strokovnih člankih navaja naslednje: »V reviji izstopa tudi skupina likovnih umetnic s predstavitvami Leonore Lavrin, Anice Zupanec Sodnikove, Dane Pajnič, Bare Remec in Karle Bulovec [...].« 
državna meja z Italijo po drugi svetovni vojni ločila od matične Slovenije. Na večino Dobidovih vprašanj je Pavla Makuc odgovorila v ličnem rokopisu. Ob danes že znanih podatkih o slikarki Meliti Rojic je njena sestrična navedla tudi manj znane drobce iz njenega življenja. Vsebina pisma je naslednja:

Spoštovani gospod ravnatelj!

Oprostite, da tako pozno odgovarjam na Vaša cenjena pisma. Je zadnji mesec šole in zato dela pre obilo. Srčno me veseli, da nameravate sprejeti sestrično Melito Rojic $v$ Slovenski biografski leksikon in Vam z veseljem postrežem $v$ kolikor mi je za sedaj mogoče.

1. Datum smrti in rojstva bom iskala po šolskem zaključku na goriškem občinskem uradu, ako Vam med tem ne postreže čast. s. Ahacija Kacin, predstojnica v slov. sirotišču "Sveta Družina" ul. Don Bosco, katero sem obvestila o Vaši želji, ker je sirotišče dedič premičnin in neprimičnin po izumrli družini Dr. Rojic.

2. Podatki o starših: Oče, Dr. Aleksij Rojic, doma iz Zalošč pri Dorenbergu, brat pok. Dr. Ferdinanda Rojic, ki je rešil življenje pesniku S. Gregorčiču, ko ga je v cerkvi na Gradiškuti zadela kap pred oltarjem, zdravnik in nekaj časa državni poslanec na Dunaju. - Mati: Ana plem. Dolšajn iz Postojne. ${ }^{6}$ (Prim.: Koršič, 1987, 220-221; Koršič Zorn, 2000, 31-32.)

3. Slikanja se je učila pri gospej Šantelj, soprogi gimnazijskega profesorja in materi slikarja Saša Šantelj.

4. Vem, da se je udeležila mnogih razstav. O tem mi je mnogo pripovedovala -a jaz sem pozabila kje. Meni je dala mnogo prekoristnih navodil za poučevanje risanja na ženskih pripravnicah za učiteljišče.

5. Njena dela se nahajajo v sirotišču, deloma v družini Dr. A. Kacin v Gorici, ul. Contavalle 5 in tri slike so pri meni, ker jih je pokojni stric [Melitin oče] po njeni smrti osebno daroval moji sestri in meni. Stric je bil brat moje matere.

6. Nekaj njenih slik je objavil »Slovan " pred prvo svet. vojno. Morda je tudi kaj pisal o njenih razstavah. Vem da si je dopisovala $z$ madžarsko slikarico cvetic $g$. Irmo Demetzky, in da sta skupno razstavljali.

7. Vsako poletje so šli na letovišče na Bled, v Boh. Bistrico in še v druge kraje.

O tem bi Vam kaj več poročala čast. sestra Ahacija, ker so vso korespondenco hranili.

Med počitnicami je iskala in kupovala pri kmetih starinske originalne narodne noše: pristne avbe, svilene rute, predpasnike, životke. Bila je vesela,

6 Novejši podatki kažejo, da je bila mati Ana Frančiška Dolšajn/Dolschein rojena v Lipi, Istra, dne 10. novembra 1855.

7 Na moje poizvedovanje mi je gospa Erzsébet Tatai (Research Institute for Art History of the Hungarian Academy of Sciences, Budapest) sporočila, da nimajo nikakršnega gradiva o Meliti Rojic, ki bi bilo vloženo v dokumentacijo o Irmi Demetzky, niti v katero drugo. 
temperamentna. Igrala je glasovir in gosli. Imela je skupno s sestro Edito domače učiteljice in kateheta Dr. Hilarija Zorna.

$V$ zapuščini je lepa stenska slika njene matere, slika njena skupaj s sestro, in slika starega očeta in stare matere, Antonija in Terezije Rojic. To vem, ker so bile slike na stenah in sem jih o priliki obiskov občudovala.

Tudi osebnih fotografij mora biti precej in to tudi iz njene mladosti.

Ko sem nesla Vaše prvo pismo, oziroma pismo, katerega mi je pisala $v$ Vašem imenu gosp. tajnica v sirotišče, mi je darovala čast. s. Ahacija onih 11 nanizanih razglednic, ki sem Vam jih poslala po Lojzetu Lisjaku iz Oševljeka. Original malega stolpiča je pri meni. O dečku mi je pisala na Dunaj. Hodil je k njej za model. Nekoč je splezal na brzojavni drog in zgorel vsled elektr. toka. Se vidi, da jo je družila $z$ modelom notranja vez. O počitnicah bom poiskala med staro korespondenco, če dobim še kaj zanimivega.

Čast. s. Ahacija me je prosila naj Vam pišem, da ji oprostite ker nima sedaj časa iskati med zapuščeno korespondenco, a kakor hitro bo prosta Vam bo pisala.

Najsrčnejša hvala g. tajnici za prijazni spominek $v$ katerem je ohranjeno naše dunajsko zavetišče. O počitnicah bom pisala tudi nje. Jaz namreč še učim ker sem "fuori ruolo" in ne bom imela penzije temveč le invalidnino.

$S$ prevdanim pozdravom

Makuc Pavla

(Pripisano: Došlo: 24. V. 58)

Sledili sta Dobidova zahvala in ponovna prošnja za posredovanje manjkajočih slikarkinih biografskih podatkov, ki jih je čez čas Pavla Makuc (Arhiv Narodne galerije, Gorica, 15. junij 1958, št. 79/5) poslala v Narodno galerijo. Karel Dobida je $\mathrm{v}$ dopisovanju s slikarkino sestrično od nje prejel 11 razglednic $\mathrm{z}$ reprodukcijami akvarelnih motivov. Koliko akvarelov je slikarka izdala na razglednicah, trenutno ni mogoče ugotoviti. Iz tistih, ki jih hrani Narodna galerija, pa je razvidno, da so izšle v visokih nakladah, kar potrjuje, da si je Melita Rojic tako kot drugi vesnani prizadevala svoje slikarske vizije predstaviti množicam. Šele ko bo njen celoten opus ovrednoten, bo tudi razvidno, kolikšen delež njenih akvarelov je bil pozneje natisnjen na razglednicah. 


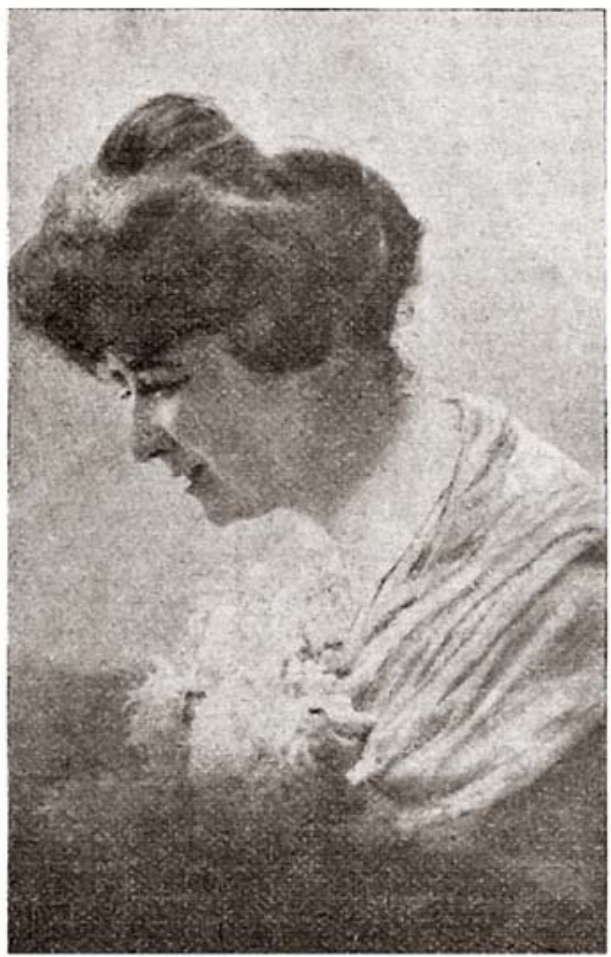

Slika 1: Fotografski portret slikarke.

Vir: Ženski svet, 4, 1926, str. 97.

\section{Članica akademskega društva Vesna}

Preden razglednice pobliže predstavim, naj spomnim, da se je v zvezi z društvom Vesna (Arhiv Narodne galerije, Gorica, 15. junij 1958, št. 79/5; Žerovc, 1999, 53) umetnostnozgodovinska stroka do sedaj ukvarjala predvsem z njegovimi člani, nič ali zelo malo pa s članicami. Zato navajam Saša Šantla (1941/1942, 174), ki je naštel vse:

In tako je prišlo v jeseni 1903 do ustanovnega občnega zbora. Bilo nas je precej. Od Hrvatov smo šteli za svoje člane Baškovića, Hrena, Kerdića, Meštrovića in Muho, od Slovencev imam pa v spominu sledeča imena: Abram Mimi, Ajlez, Bernhold (izredni), Birolla, Gaspari, Gaber, Klemenčič Fr., Koželj Maks, Kreševič Jelisava, Kuželički, Novak Zalka, Peruzzi, Rakovec Minka, Rojic Melita (izr.), Sever Ruža, Sever Vilko, Šantel Avgusta (izr.), Šantel Saša in Zolja. Kar je bilo ženskih članov so bile učenke na oddelku za ornamentiko in umetno vezenje (Kunstgewerbeschule). Pozneje se nam je pridružil tudi Smrekar. Bilo nas je torej lepo število, ki se je vrtelo ves čas okoli 20. 
Da je bila Melita Rojic članica Vesne, potrdi tudi beograjski razstavni katalog (Katalog, 1904, 29), kjer je v rubriki Slovenci ${ }^{8}$ pod imeni slikarjev in kiparjev navedeno, kateri umetniški družbi pripadajo, torej ali akademskemu društvu Vesna na Dunaju ${ }^{9}$ ali umetniškemu društvu Sava, Ljubljana; pri tistih slovenskih umetnikih, ki niso bili "opredeljeni«, pa je bil prostor pod imenom in priimkom prazen. Pod imenom Melite Rojic je natisnjeno »članica Vesne«. Dodatno potrditev je prispevala Beti Žerovc, ko je v zapisniku občnega zbora z dne 15. 1. 1904 našla podatek, da je takrat Melita Rojic pristopila k Vesni kot izredna članica iz Gorice (Žerovc, 1999, 58). Kot »vesnanka» je Melita Rojic očitno sledila programski usmeritvi umetniškega društva in tako kot drugi člani pričela izdajati svoje akvarelne motive na razglednicah. Da je bila to ena od programskih nalog vesnanov že v času dunajskega študija, je poročal Saša Šantel (1941/1942, 96; 2006, 174-175):

Slovenske razglednice so bile takrat še redkost. Zato je bila naša serija sprejeta po večini z velikim zadovoljstvom. Pošiljali smo jih po vseh krajih domovine in prinesle so naši blagajni toliko dohodkov, da smo lahko krili najpotrebnejše izdatke za lokal in pohištvo. [...] Naš ideal je bil Uprka ${ }^{10}$ in pripraviti smo hoteli pot, da bi Slovenci in Hrvatje prišli do spoznanja, da nam samo kopiranje nemških vzorov ne more prinesti slave. Slovenski narodni ornament, za katerega sta nas navduševala Gaspari in Gaber, nam je bil še neznan. Začeli smo počitniško akcijo za nabiranje narodnih ornamentov in dobro se spominjam, s kakšnim navdušenjem smo gledali kopije vezenin s peč in rut, ki so jih po prvih počitnicah zbrali nekateri člani in članice. ${ }^{11}$

8 Da je bila beograjska razstava za nekatere člane Vesne tudi finančno uspešna, piše Maksim Gaspari prijatelju (Mikuž, 1978, 25): »Druga novica je, da je prišel denar iz Belgrada. Jaz in Birolla sva največ prodala. Jaz menim, da dobim za vse skupaj okrog $300 \mathrm{~K}$, ker, prvič Srbi plačujejo vse v dinarjih, drugič razne procente za Vesno itd. [...], med kupci pa je bil tudi muzej, ki je kupil slikarjeva dela za svoje zbirke!«

9 Člani akademskega umetniškega društva Vesna, ki jih navaja beograjski katalog, so: Avgust Bertold; Avgusta Šantel; Aleksander - Saša Šantel; Gvido Birolla; Zalka Novakova; Ivan Kerdić; Josip Aljanc; Josip Zolja; Maksim Gaspari; Melita Rojic; Minka Rakovec; Ružica Sever; Svetozar M. Peruzzi; Hinko Smrekar.

10 Joža Uprka (1861-1940) je bil moravski slikar in grafik, predstavnik romantičnega historicizma in secesije. Njegovo delo zajema etnografske, folklorne motive, predvsem iz južne Moravske.

11 »Društvo je začelo takoj akcijo za nabiranje etnografskega blaga in vsak član se je moral zavezati, da o počitnicah preriše ali drugače nabere čim več narodnega etnografskega gradiva. [...] Šest takih slik smo dali reproducirati ter natisniti v razmeroma veliki nakladi. Razpošiljali smo jih na razne naslove $\mathrm{v}$ domovini in prinesle so nam precej denarja, s katerim smo postavili svoje blagajniško poslovanje na trdne noge.« Glej Prilogo 4. V že citiranem pismu iz decembra 1903 Saša Šantel sestri sporoča: »Včeraj je bil III. obč. zbor, ki je bil skoro polnoštevilno obiskan. Še nikdar ni bilo tako zanimivo kakor včeraj. Najzanimivejša je bila predzadnja točka dnevnega reda, poročilo jury-ja za razglednice in razdelitev nagrad. Do takrat ni imel nihče pojma, kako je stvar izpadla. In glej srečo, I. nagrada je doletela mene. [...] II. nagrado je dobil Gaspari. [...] V celem je sprejetih 6 razglednic. Upamo, da bodo napravile mnogo efekta.« 
Da je tudi Melita Rojic med počitnicami pri kmetih zbirala in kupovala »starinske originalne narodne noše: pristne avbe, svilene rute, predpasnike, životke« (glej korespondenco: Pavla Makuc, 24. 5. 58, 7. točka), je Dobidi iz prve roke poročala njena sestrična. Študij originalnih narodnih noš je Melito Rojic spodbudil k akvarelnemu ustvarjanju. Kar na dveh slikarkinih razgledniških motivih sta upodobljeni ženski, oblečeni v narodna oblačila $\mathrm{z}$ avbo, tudi portret dečka v vsakdanji opravi s klobukom na glavi je etnološko zasnovan, $v$ upodabljanje stavbne dediščine pa lahko štejemo Stari stolpič in Črna prst v Bohinjski Bistrici. Da je slikarka motive iz slovenske narodne zakladnice pričela zajemati dokaj zgodaj, namreč kmalu po ustanovitvi Vesne, namigujejo nekateri naslovi del, ki so bila zastopana na razstavah iz prve polovice prvega desetletja 20. stoletja. Na II. slovenski umetniški razstavi v Ljubljani leta 1902 je triindvajsetletna razstavila tri akvarele. V razstavnem katalogu (Seznam, 1902, 7-8) so navedeni tile: »122. Rojic Melita: Ulica 'Campo delle scale' v Gradežu. 123. Rojic Melita: Lepotica iz Čedada. 125. Rojic Melita: Dvorišče v Lescah.«V razstavnem katalogu iz leta 1904 na I. jugoslovanski umetniški razstavi v Beogradu (Katalog, 1904, 29) sta bili navedeni tile: »397. Ulica Campo delle scale u l' radežu [pravilno v Gradežu]; 398. Dvorište u Kranjskoj. «Katalog prve slovenske umetniške razstave v Trstu leta 1907 (Katalog, 1907, b. p.) navaja kar šest njenih del, in sicer: "65. Motiv iz Bohinja. 66. Goriški postopač. 67. Kranjica. 68. Na Gradu. 69. V podstrešju. 70. Motiv iz Lesec.« Obstoj akademskega društva Vesna je bil kratkega daha, saj je konec poletja 1906 prenehalo delovati (Žerovc, 1999, 51), društveno nalogo izdajanja razglednic pa je Melita Rojic posvojila in svoje akvarelne motive izdajala tudi pozneje.

\section{Motivi na razglednicah, hranjenih $v$ Narodni galeriji}

Na vseh razgledniških motivih je avtorica podpisana z M. Rojic. Med razglednicami sta dva para po motivu ista: Kranjsko dekle in Kranjski fantič, oziroma Joža $z$ Bleda, ki sta izdana v dveh tonih, v črno-beli in rdečerjavkasti varianti. Drugi motiv je v črnobeli reprodukciji naslovljen Kranjski fantič, v rdečerjavem tonu pa Joža z Bleda; tudi podatki na zadnji strani teh dveh variant se nekoliko razlikujejo. Precej motivov Melite Rojic so objavili v reviji Slovan (Umetnostna, 1906/1907; 1909; 1912, [113, 177, 289, 320-321]): leta 1906/1907 Portretno študijo, leta 1909 Študijo (starka v profilu), leta 1912 so natisnili kar štiri motive (Študija, doprsje ženske v profilu; Študija, ženska s klobukom; Bled; Študija) in pripisali (Umetnostna, 1912, 320): »Radujemo se, da moremo svojim čitateljem zopet predstaviti našo goriško umetnico Melito Rojčevo. "Na dopisnici, ki jo je naslovila na dr. Frana Ilešiča, urednika Slovana, je slikarka napisala:

Velecenjeni gospod doktor! Cenjeno Vašo dopisnico sem prejela ter Vam s tem naznanjam, da Vam pošljem naprošeno v kratkem. Tedaj Vam pošljem ob enem tudi kako sliko, katero bi utegnili morebiti porabiti za urejanje "Slovana" 
ali pa - ako se Vam bo zdelo - poslati jo "Savremeniku«. Klišejev pa nimam razen »Kranjico" in »Bled«. Ti dve pošljem v Zagreb. Klišeji drugih mojih slik, poseduje pa tiskarna Ottmar Zieher v Monakovem. Z odličnim spoštovanjem, udana Melita Rojic. V Gorici, 26. 2. 913 (Melita Rojic, MS 1492, mapa 82; 7, 1913-1914).

$\mathrm{V}$ naslednjem pismu uredniku sporoča:

Velecenjeni gospod doktor! Zelo bi me zanimalo izvedeti ali ste si izposlanih slik izbrali kaj in ali ste kaj že začeli objavljati za »Slovana«. Kadar slike odrabite, blagovolite mi jih vrniti, ker jih večkrat rabim. Z odličnim spoštovanjem udana Melita Rojic, v Gorici, 4. 4. 13 (Melita Rojic, MS 1492, mapa 82; 7, 1913-1914).

Čez dober mesec Melita Rojic na dopisnici dr. Franu Ilešiču sporoča prošnjo:

Velecenjeni gospod doktor! Prosim lepo izvolite doposlati mi prej ko mogoče 'Kranjico' (študija: enobarvna rudeča ženska glava) in ako le mogoče tudi 'Jožeta', ker ju sedaj rabim. Kaj pa 'Savremenik'? Rada bi vedela, - ako Vam ljubo mi naznaniti - jeli že prinesel moje slike? Pozdravljam lepo Vas, velecenjeni gospod doktor, ter gospoda Magoliča in Hribarja. Z odličnim spoštovanjem. Udana Melita Rojic. Gorica, 8. 5. 913 (Melita Rojic, MS 1492, mapa 82, 1913-1914).

In spet čez dva meseca slikarka piše:

Velecenjeni gospod doktor! Ker vem, da se vstreže 'Slovanu' s klišeji pošiljam Vam priloženi kliše od katerega sem strila natisniti sama 1000 razglednic. Ako ga torej porabite, pošljite mi 2 iztisa dotičnega 'Slovana' in kliše. V Zagreb sem pisala pa odgovora le še ni.- Lepo pozdravljam gospoda Magoliča in Hribarja, ter $z$ odličnim spoštovanjem in prijaznim pozdravom udana Melita Rojic. Gorica, 3. 7. 13 (Melita Rojic, MS 1492, mapa 82; 7, 1913 -1914).

Septembra istega leta je na razglednici z motivom "Joža» slikarka uredniku Slovana in Hribarjevi tiskarni napisala:

Gorica, 20. 9. 13 Velecenjeni gospod doktor! Kliše 'Joža z Bleda' Vam bodem v kratkem poslala.-Blagovolite mi pa prej kot mogoče vrniti moje akvarele, ker jih sedaj rabim. Z odličnim spoštovanjem udana Melita Rojic.

Zadnje pismo Franu Ilešiču pa je poslala, ko je ta postal profesor v Zagrebu: Velecenjeni gospod doktor! V kratkem sem izvedela, da ste dobili tako častno povabilo na zagrebško vseučilišče. Dovolite, velecenjeni gospod profesor, da Vam s temi vrsticami prav iskreno čestitam. Ob enem se predrznem Vas opozoriti, ko boste $v$ Zagrebu, in si ogledate tamošnjo mednarodno umetniško razstavo - na 
goriškega slikarja Delnerija. ${ }^{12}$ On in družina njegova so sicer laške narodnosti, ali rodom Goričani, mestni in zelo ugledni, ki tudi med Slovenci delujejo. Vrhu tega je ta akademično izobraženi slikar že imel dosti uspehov in priznanj, posebno $v$ dunajskem 'Kunstlerhaus' - Ker je naš stari znanec, ga priporočam posebno za dobrohotno kritiko, ker jo tudi res zasluži, posebno kot 'Radierer'. - Oprostite moji nadlegi in sprejmite, velecenjeni gospod profesor, moj vljudni poklon. Vam udana Melita Rojic. V Gorici, 2. II. 914 (Melita Rojic, MS 1492, mapa 82; 7, 1913-1914).

Dopisovanje med likovno ustvarjalko in urednikom Slovana je rodilo sadove. Tako so leta 1913 objavili (Umetnostna, 1913, 281, 355) njena motiva Kranjsko dekle ${ }^{13}$ in Gorica $v$ snegu, med prvo svetovno vojno, leta 1915, pa še eno njeno Študijo (Umetnostna, 1915, 156). Več teh motivov je bilo izdanih tudi kot razglednice. Izmed galerijskih se z objavami v Slovanu ujemajo naslednje: Portretna študija, Bled, Študija, na razglednici ima naslov Kranjica, Kranjsko dekle in Študija, ki je na razglednici naslovljena Joža z Bleda oziroma Kranjski fantič. Dvojezični naslovi na hrbtni strani galerijskih razglednic vsaj pri nekaterih nakazujejo, da so bile natisnjene $\mathrm{v}$ predvojnem obdobju, $\mathrm{v}$ času avstro-ogrske monarhije, o čemer posredno govorijo tudi naslovi, napisani v slovenščini in nemščini (Bled/Veldes, Kranjica/Krainerin, Kranjsko dekle/Mädchen aus Krain, Kranjski fantič/Krainer Bub ali pripis (pred vojno) Kanal ob Soči). Ta pripis govori, da je razglednica pač izdana po vojni, kaže pa predvojno podobo kraja. Njena sestrična Pavla Makuc je v pismu ravnatelju Dobidi zapisala, da so vsako poletje letovali na Bledu, v Bohinjski Bistrici ali v drugih krajih. Ta informacija podkrepljuje domnevo, da so že pred prvo svetovno vojno nastali tudi nekateri drugi razgledniški motivi, ki jih sicer ne najdemo v Slovanu. Pri natančni določitvi kronologije slikarkinega opusa pa bo treba upoštevati tudi dejstvo, da se je družina Rojic pred strahotami vojne umaknila iz Gorice in so kot begunci živeli na Bledu. Tako je mogoče, da je akvarelistka nekatere gorenjske motive naslikala tudi v tem obdobju. Umetnostna zgodovinarka Verena Koršič Zorn (2000, 31-32), sicer poznavalka njenega opusa, je tako ovrednotila njene akvarele:

12 Priimek Delneri so spremenili v Del Neri leta 1915, zato ga Melita Rojic v pismu še zapiše v stari inačici.

13 Melita Rojic v pismu, poslanem Franu Ilešiču, omenja tudi hrvaško knjižno revijo Savremenik, kamor je nameravala poslati svoja dela. Vendar je bilo pri pregledu letnikov od leta 1913 do 1920 ugotovljeno, da Savremenik ni objavil njenih akvarelov. Tu so natisnili dela hrvaških slikark, med njimi Naste Rojc, in drugih sodobnih hrvaških likovnih ustvarjalcev, med slovenskimi pa je bilo leta 1914 ([Umetnostna], 1914, sl. [421]) objavljeno le delo Ivana Vavpotiča, Šarka. Po primerjavi objavljenih Vavpotičevih del v razstavnem katalogu iz leta 1987 je ta motiv naslovljen Ob nevihti. Očitno je, da je prvotni naslov platna utonil v pozabo. Delo je datirano v leto 1907, ko je Vavpotič že stanoval v Idriji, zato je Milček Komelj (1987, 81, sl. 13) upravičeno trdil, da naslikane pokrajine ni mogoče lokalizirati v idrijski prostor. Vavpotičevo delo mora spet dobiti prvotni naslov, torej Šarka, kajti to je naravni rezervat na severovzhodnem obrobju Prage. 
Rojičeva se je najraje posvečala akvarelu, ki sicer ni enostavna tehnika. Od slikarja zahteva že veliko izurjenost, samozavesti in gotovosti v potezah. Ohranjena dela nam razkrivajo slikarko z dobrim tehničnim znanjem, ki sicer ne išče novih motivnih in vsebinskih prijemov, ostaja pa $\mathrm{v}$ koraku $\mathrm{s}$ splošno naravnanostjo umetnostnih teženj časa.

V italijanski študiji $(2005,146)$ jo označi kot »akvarelistko, občutljivo za naravne lepote in izraznost človeškega obraza«. Če o njenih akvarelih piše odobravajoče, pa je do njenih razgledniških motivov kritična $(1979,334)$ :

Do sedaj smojo šenajboljpoznali izkrajinskih slik, ki sojih večkrat reproducirali na razglednicah (med njimi tudi Kanal). Tu pa slikarka ni najboljša. Včasih se zdi, kot da se je zavestno predala nekakšnemu »razgledniškemu« slogu, ta pa ne daje prave slikarske podobe.

Če ne drugega, imajo danes ti razgledniški krajinski motivi nedvomno dokumentarno vrednost. Poleg tega tovrstne upodobitve krajev pomenijo nadaljevanje nekdanjega vedutnega slikarstva, saj sodobnikom pogosto edine izpričujejo nekdanjo podobo slovenskih krajev, ne le panoram, marveč tudi posameznih ožjih predelov (Komelj, 2003, 322). Najbrž je kritika Verene Koršič za razglednice s krajinskimi motivi ustrezna, manj pa za motive, na katerih je zajeta snov z etnološko dediščino, kamor bi lahko prišteli vsaj dvoje slikarkinih motivov: Kranjica oziroma Dekle, ki lupi jabolko, in Kranjsko dekle. Ta dva razgledniška motiva Melito Rojic predstavita kot dobro akvarelistko. Ob portretih, krajinah in etnoloških motivih so jo pritegnili tudi industrijski objekti, kar je v tem času izjemno, saj druge slikarke niso slikale tovrstnih motivov. Od enajstih razglednic v lasti Narodne galerije jih je v nadaljevanju predstavljenih šest.

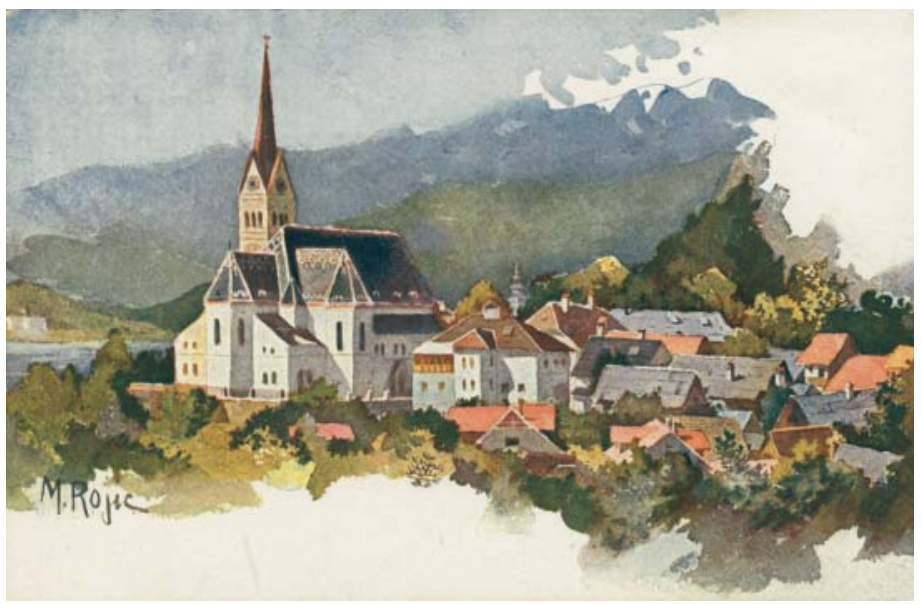

Slika 2: Bled, 14 x 9,1 cm [1912], barvna reprodukcija.

Vir: Arhiv Narodne galerije. 
Na hrbtni strani razglednice je dvojezični napis Dopisnica Postkarte, naslov: Bled/ Veldes, v rokopisu je dodano: Firma Jasper Vienna 4.500 pezzi, Veldes Jugoslavia.

Tudi ta reprodukcija je bila objavljena v Slovanu (1912 [289]) in na podlagi slikarkinega motiva je bila natisnjena barvna razglednica, na kateri je avtorica dala poudarek na historicistično cerkev sv. Martina, ki je bila zgrajena v letih 1904-1905, in na blejski predel, imenovan Grad. Ob modrozelenem koloritu izstopajo kontrastne rdečkaste strehe hiš. Na desnem zgornjem delu in na vsej spodnji ploskvi razglednice se razprostira belina nosilca, ki jo ponekod zalivajo prozornejše akvarelne barve. Bržkone je bila razglednica natisnjena po prvi svetovni vojni, ker je na hrbtišču v rokopisu dodano Veldes Jugoslavia.

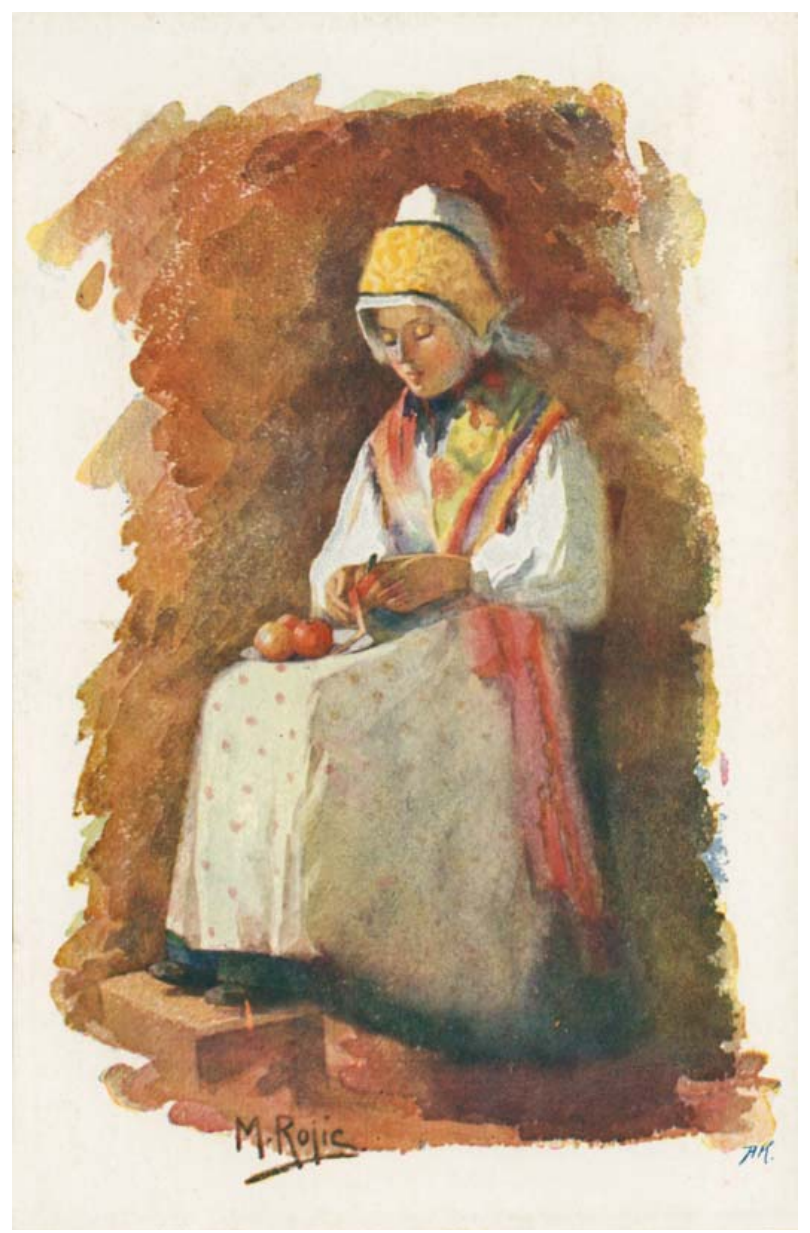

Slika 3: Kranjica, 9 x $14 \mathrm{~cm}$ [1912], barvna reprodukcija. Vir: Arhiv Narodne galerije. 
Na hrbtni strani razglednice je dvojezični napis Dopisnica Postkarte, naslov: Kranjica/Krainerin, v rokopisu je dodano: Firma Jasper Vienna 20.000 pezzi.

Barvna reprodukcija motiva je bila objavljena v Slovanu leta 1912 (Umetnostna, 1912 [321]) pod naslovom Študija. Najbrž je identična z motivom, ki ga v strokovni literaturi najdemo pod naslovom Dekle, ki lupi jabolka. O tako naslovljenem delu Verena Koršič $(1979,336)$ domneva: »Ni izključeno, da je Melita Rojic poznala tudi Ivano Kobilco, če ne osebno, pa vsaj po delu. Nekateri sorodni motivi (npr. Dekle, ki lupi jabolka) in podobno zajete figure to možnost potrjujejo.«

Sedeče dekle, zajeto tričetrtinsko s strani, je odeto v svetlo narodno nošo, na glavi ima rumeno obrobljeno avbo in okoli ramen pisano rdečkastorumeno ruto. Noge ji počivajo na podnožniku. Mladenka je v naročje položila jabolka, eno pa obrezuje $\mathrm{z}$ nožičem. Ozadje $\mathrm{v}$ okrastorjavih in ponekod zelenkastih niansah je naneseno $\mathrm{v}$ sproščenih potezah čopiča.

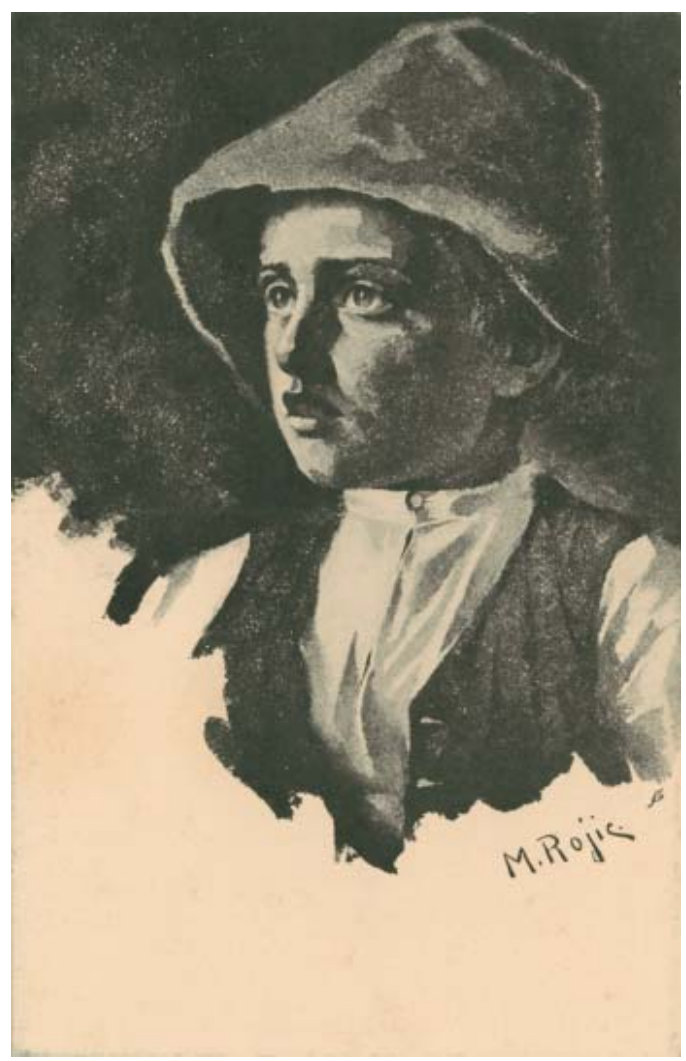

Slika 4: Kranjski fantič, 8,8 x 13,8 cm [1915], črno-bela reprodukcija. Vir: Arhiv Narodne galerije. 
Na hrbtni strani natisnjeno: Dopisnica/Postkarte, naslov: Kranjski fantič/Krainer $B u b$, v rokopisu dodano: Firma Jasper Vienna 1.500 pezzi.

Leta 1915 je bil motiv reproduciran v Slovanu (Umetnostna, 1915, 156) pod naslovom Študija. Na razglednicah pa je v črno-beli izdaji, kakršna je tudi v Slovanu, naslovljen kot Kranjski fantič, na drugem, rdečkastorjavem toniranem razgledniškem motivu pa kot Joža $z$ Bleda. V pismu, naslovljenem na Karla Dobida, je Pavla Makuc opozorila, da je bil deček slikarkin model.

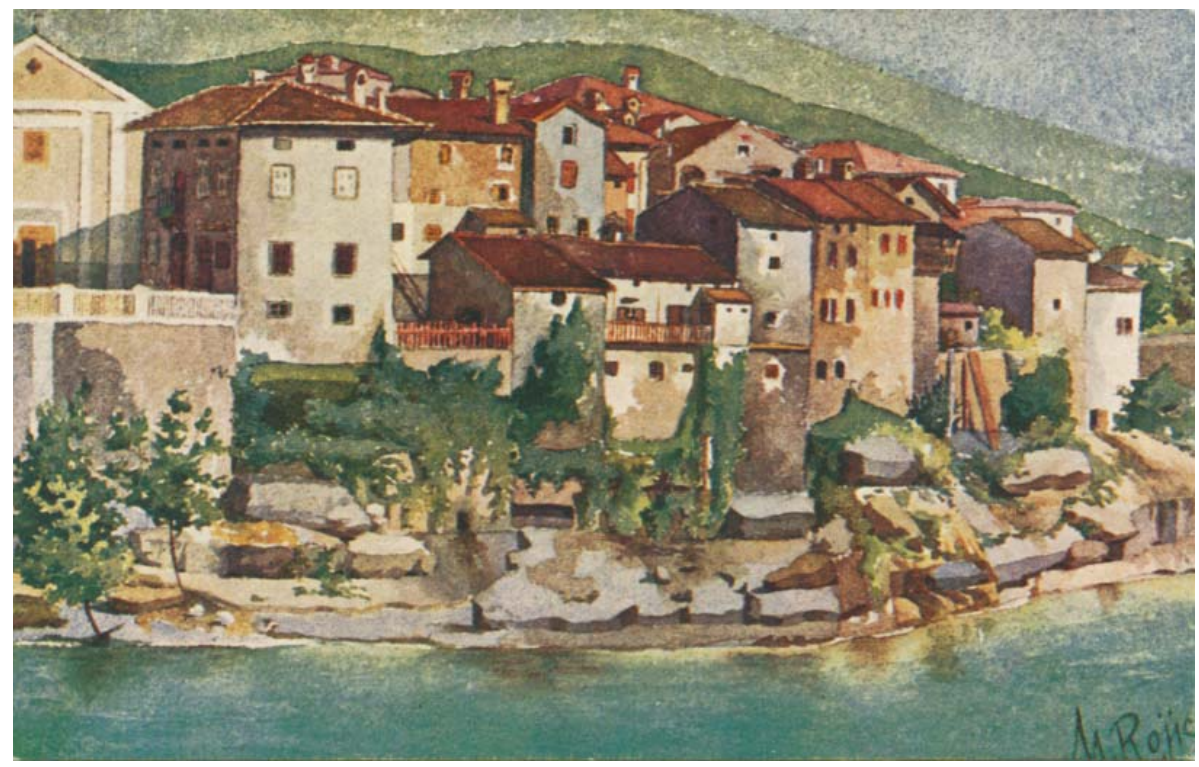

Slika 5: Kanal ob Soči (pred vojno), 13,8 x 8,8 cm, barvna reprodukcija.

Vir: Arhiv Narodne galerije.

Na hrbtni strani naslov motiva: Kanal ob Soči (pred vojno). Canale d'Isonzo (avanti guerra), v tiskanih črkah natisnjeno: Edit.: Jos. Baudaž. M. Rojic, v rokopisu pripisano: Arti grafiche Bergamo 10.000 pezzi.

Tokrat je slikarka upodobila pogled na Kanal z nasprotnega brega Soče in kraj naslikala iz žabje perspektive. Zajela je skalno nabrežje z zelenimi drevesi, nad njim so tesno skupaj zgrajene hiše. 


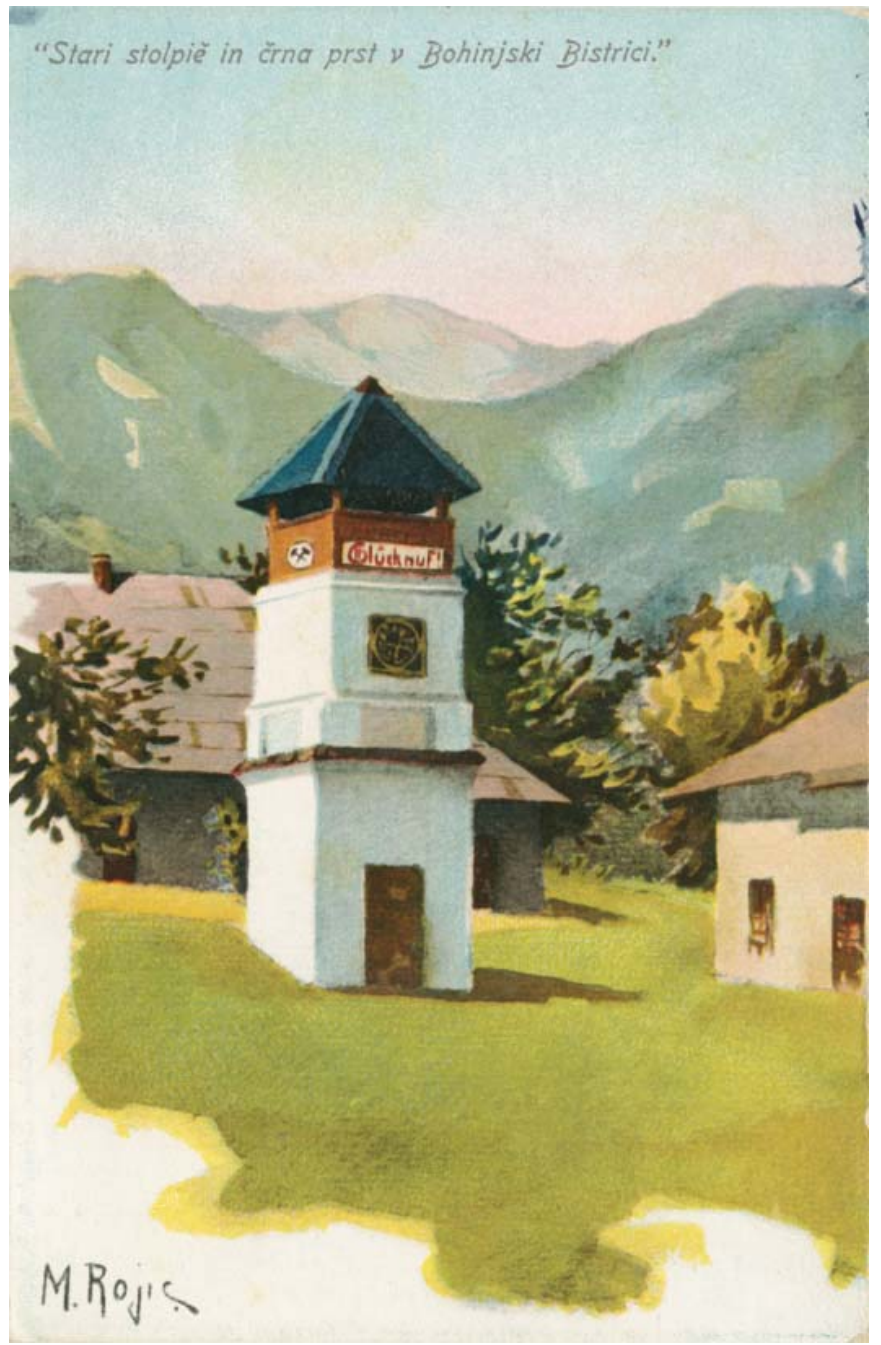

Slika 6: Stari stolpič in Črna prst v Bohinjski Bistrici (Zoisova stolpna ura), $9 \times 14 \mathrm{~cm}$, barvna reprodukcija.

Vir: Arhiv Narodne galerije.

Na licu razglednice je natisnjeno: »Stari stolpič in črna prst v Bohinjski Bistrici«, na hrbtni strani pa: Dopisnica in na robu: Ottmar Zieher, München, v rokopisu: Ottmar Zieher cirka 3.50081.

Pavla Makuc v pismu ravnatelju Dobidi navaja: „Original malega stolpiča je pri meni.« Predvidevam, da gre na razglednici za motiv, ki ga omenja slikarkina sestrična. Ta industrijski objekt ni edini, ki ga je Melita Rojic naslikala v akvarelu 
(Koršič, 1979, 335-336). ${ }^{14}$ Stolpič je umestila v središče kompozicije in ga pred barvitim ozadjem poudarila $\mathrm{z}$ belino sten. Pod modrikasto štirikapno streho je na rjavkastem nosilcu na eni strani narisan rudarski simbol - prekrižani kladivi -, na drugi strani pa je napisan rudarski pozdrav Glückauf! (Srečno!). Pod njim je na belo steno vstavljena ura na temni podlagi. Na sodobnih fotografijah je na stolpiču zapisan priimek Zois. Ko so leta 2006 stolpič z uro obnovili, so predvidevali, da ga je zgradil eden od Zoisov, ki so bili v času 1749-1836 lastniki bistriškega gradu, pred katerim v parku stoji ta stolpič. Pomenljivo je, da v Bohinjski Bistrici takrat še ni bilo cerkvene ure (Felc, 2006, 17).

Septembra 1788 je Žiga Zois izdal rudarski red za bohinjske obrate in uvedel pogodbeno rudarjenje. Ivan Veber navaja, da je tedaj delalo 170 rudarjev v štirih revirjih, enem na Jelovici in treh na Pokljuki. Na koncu rudarskega reda je še nekaj podrobnih navodil za delo v železarni. Za reden začetek in konec dela pa je potrebna ura.

Zoisov stolpič z uro je torej nastal, da bi delavci in železarji pravočasno prišli na delo. Uro so morali ročno navijati enkrat na dan.

\section{Zaključek}

Do sedaj pisci o Meliti Rojic niso izpostavljali dejstva, da je bila članica Vesne, v članku pa poskušamo pokazati, da je slikarka posvojila naloge društva, kar je posredno vplivalo na izbiro njenih »etnoloških« motivov. Še več, uresničila je pomembno društveno zahtevo po izdajanju razgledniških motivov, sicer resda potem, ko je društvo že zamrlo. Ob tej prvotni spodbudi se je slikarka za natis odločila nedvomno tudi zato, ker je po letu 1897 in vse do prve svetovne vojne mogoče zaznati porast izdajanja razglednic. "Tedaj je postalo pošiljanje pa tudi zbiranje razglednic prava moda, celo 'epidemija', " pravi Komelj (2003, 321-322). Fran Ilešič, ki je bil "pristaš novega ilirizma«, in Ivan Trnski, njen sorodnik po materini strani, sicer pa hrvaški pesnik, prevajalec, predvsem pa narodni buditelj, sta bila svetovnonazorsko blizu slikarkini usmeritvi. Kljub dogovarjanju o natisu njenih del v hrvaški knjižni reviji Savremenik do objav ni prišlo. Melito Rojic prav dopisovanje z Ilešičem predstavlja kot razgledano, predvsem pa poučeno o likovnem dogajanju. Nikakor pa se slikarka ni zapirala samo v ta krog, temveč je vzdrževala stike z goriškim slikarjem Edoardom Del Nerijem (18901932) (Malni Pascoletti, 1990; Martelli, 2001, 127-128; Delneri, Sgubin, 2005), ${ }^{15}$ ki ga

14 Naj spomnim na akvarel Industrijski obrat (s Stolom v ozadju), ki ga hrani Goriški muzej. Mere akvarela so: $24,5 \times 16,3 \mathrm{~cm}$.

15 Melita Rojic upravičeno govori o uspešnem slikarju in grafiku, poznavalci pa ga označujejo prav tako kot oblikovalca in ilustratorja. Od leta 1914 je živel in ustvarjal v Rimu. Udeleževal se je pomembnih razstav v Italiji in tujini. Zagrebško razstavo, na kateri je grafike razstavljal tudi Edoardo Del Neri in 
v enem izmed pisem omenja »kot našega starega znanca«. Mimogrede, njegova mati Caterina Paulin je bila sodeč po dekliškem priimku slovenskih korenin. Slikarka pa je prav gotovo poznala tudi Edoardovega očeta Clementa Delnerija (1865-1943), ${ }^{16} \mathrm{ki}$ je v Zaloščah, v rojstni vasi slikarkinega očeta, v cerkvi sv. Lovrenca slikal v fresko tehniki. Vendar slikarja na Melito Rojic nista ustvarjalno vplivala. Korespondenca je razkrila tudi madžarsko slikarko Irmo Demetzky, poročeno Wolf, s katero si je Melita Rojic dopisovala in s katero sta tudi skupaj razstavljali. Kot Melitta Rojic (Schweiger, 2003) je našteta med članicami Društva likovnih umetnic (Vereiningung bildender Künstlerinnen) in zato sklepamo, da ji je prav to društvo omogočilo razstavljanje v avstrijskih in nemških mestih, za katere dotlej nismo vedeli, jih pa slikarka našteva $\mathrm{v}$ rokopisni biografiji. Našteti drobci, vzeti iz korespondence in drugih virov, bodo podlaga za sestavljanje kompleksnejše slikarkine biografije in - obetamo si - za natančnejše ovrednotenje njenega slikarskega opusa.

ki jo omenja Melita Rojic v pismu Ilešiču, potrdita tudi citirani razstavni katalog iz leta 2005 (Del Neri, 2005, 141): »1914 [...] Zagabria, 'Esposizione Internazionale di Grafica' «, in seveda še prej razstavni katalog Medjunarodna grafička izložba, Zagreb veljača 1914, na kateri je ob mednarodni udeležbi ob Edoardu Delneriju (še stara uporaba priimka, op. L. T.) svoja dela predstavil tudi Saša Šantel. Italijanski grafik je razstavil $18 \mathrm{del}$ (12 bakrorezov, 1 mezzotinto in 5 lesorezov), slovenski grafik pa 8 del (3 risbe, 4 bakroreze in 1 lesorez).

16 »Clemente Costatino Del Neri (1865-1943) je bil goriški slikar in restavrator. Osnov likovnega ustvarjanja se je izučil pri očetu ter na slikarskih tečajih v Benetkah in Rimu. Poslikal je mnoge cerkve na Primorskem in v Furlaniji, njegova slikarska dela lahko vidimo v cerkvah v Velikih Žabljah, Medani, Pliskovici, Rutu, Kobjeglavi, Komnu, Vipavskem Križu, Biljani, Štanjelu, Solkanu, Dornberku, Dobrovem, Zaloščah in drugod. Del Neri se je pretežno posvečal cerkvenemu slikarstvu. V cerkvi sv. Lovrenca v Zaloščah je poslikal osrednjo fresko Mučeništvo sv. Lovrenca $\mathrm{z}$ angeli na nebu na stropu cerkvene ladje; fresko Štirih evangelistov na svodu prezbiterija ter fresko Pokop sv. Lovrenca v polkrožnem prostoru nad glavnim oltarjem « (FK, 2012).

Naštetih je 30 likovnih ustvarjalk, ki so skoraj vse neznane: Georgine Altman, Sofie Arnsburrg, Emma Cloeter, Gisela Czermak, Ella Ehrenberger, Martha Fuchs, Marianne Fürst, Marianne Gelmo, Ada Gòth, Hermine Haader, Fanni von Inama-Sternegg, Isa Jechl, Mary Jonas, Johanna Kaserer, Therese Kratky, Yela Liebscher, Alice Marian, Berta Pietschmann, Melitta Rojic, Therese Schachner, Therese Schneegans, Marie Schuster, Ella Struschka, Margarete Veith, Stefi Wachtel, Elise Walter, Ella Weber, Josefine Marie Weidinger, Paula Wildhack, Marie Zajackowska. Po primerjavi z novejšim leksikonom so gesla zapisana le za tri zgoraj omenjene likovne ustvarjalke, in sicer: Marianne Fürst, Marianne Gelmo in Elise Walter (prim.: Schmidt-Liebich, 2005, 155, 161, 493). 


\section{Priloga 1}

\section{IV. 1897 Gorizia xe sciava}

Članek Kaj vse pravijo!, ki je 23. aprila 1897 izšel v Soči, je bil le eden izmed odmevov na nemire, ki so na Goriškem sledili državnozborskim volitvam marca 1897 in italijanski volilni zmagi v veleposestvu. Napetost, ki je nastala med obema narodoma, se je pokazala zlasti v številnih vsakodnevnih stikih in tako Soča zapiše (Kaj, 1897, 1): »Večina nasprotnih trgovcev, obrtnikov itd. že bridko občuti posledice ogorčenosti, ki je zavladala med slovenskim prebivalstvom. Slovenci v Gorici delajo zdaj za dva in za tri, nasprotniki imajo že jako prazne prodajalnice. « Tako sta se začela prvi veliki bojkot italijanskih trgovcev in obrtnikov ter uresničevanje gesla svoji $k$ svojim, ki ga je urednik Soče Andrej Gabršček razglasil za sveto dolžnost. Vzdušje tedanjih nasprotij, nemirov in obtožb so ponazarjale tudi politične pesmi, ki so jih prepevali $\mathrm{v}$ izvirnih besedilih in glasbi ali v parodijah. Tako je po napevu italijanske sramotilne pesmi Lasse pur che canti e sub (Pustite jih, naj blebetajo) urednik Gabršček napisal slovensko predelavo: "Le pustite, naj kričijo, / naj razsajajo, norijo, / saj Gorica je slovenska / brez Slovencev Gorice ni!« Da pa ta parodija ne bi ostala osamljena, je kmalu nato napisal še eno, in sicer na napev Hej, Slovani: »Fej Lahoni, njih lahonska reč neznansko gine, / njih neznanskim krivdam kmalu vse veselje mine; / Zgini, zgini duh lahonski, vzbuja se slovenski -; / Trdno zdaj se oklenimo gesla: Svoji k svojim! « Na italijanski strani so peli druge pesmi, kot npr. Nella patria di Rossetti non si parla che Italian, ki se je prepevala predvsem med Tržačani. Za popevko Gorizia sciava oziroma Marameo (naslov bi lahko prevedli kot Pojdite že nekam), ki je imela velik uspeh med goriškimi Italijani - zlasti leta 1899 -, pa je besedilo in glasbo napisal kasnejši odvetnik Leonardo Vinci, sin goriškega župana. Zadnja kitica se glasi: »Marameo, cari burloni / Ritorne pur a Solcon / Che a Gorizia benedetta / Tutto, tutto xe Italian." / (Pojdite že nekam, dragi burkeži, vrnite se v Solkan, ker je v blaženi Gorici vse, vse italijansko). Tudi na to besedilo je Gabršček napisal parodijo: »In v naši Gorici, / da vse je 'italian'/ trdé sardaloni / neslanih možgan. / Marameo, vi makaroni, / straši vas že naš Solkan, pa tud' Gorica ta presneta / malo malo je 'italian'. / Gorica slovenska / je bila in bó, / Slovenci smo tukaj / in z nami nebó. / Marameo, brutti buffoni, / ritorne pur a Milan, / Che a Gorica benedetta / Poco poco xe italian. « Zadnjo kitico bi lahko prevedli kot: "Pojdite že nekam, grdi šaljivci, vrnite se že v Milano, ker je v blaženi Gorici malo, malo italijanskega. "Andrej Gabršček se je spominjal, da je šla pesem kot ogenj po vsej deželi: »Ubogi Lahi že niso smeli niti koraka iz Gorice, da jih niso nagnali s to pesmico ... Edino na take načine smo jih odvadili njihovih izzivalnih popevk ..."

Marušič, B., Gorizia xe sciava, v: Slovenska kronika XIX. stoletja. 1884-1899 (ur. Janez Cvirn), Ljubljana 2003, str. 272-273. 


\title{
Priloga 2 (Arhiv Narodne galerije)
}

»79/1 27. februarja 58

Predmet: Rojic Melita, slikarica - biografski podatki

Študijska knjižnica Nova Gorica

Za sestavljanje življenjepisnih podatkov slovenskih upod. umetnikov so potrebni podatki neposredno iz prvih virov. Tako nam manjkajo biografski podatki tudi za ondotno slikarico Melito Rojic, ki je bila rojena v Gorici in - kolikor smo ugotovili - je tam tudi umrla.

Prav vljudno Vas prosimo, da nam sporočite, kje bi mogli dobiti podatke o navedeni umetnici, če so bili morda že v kakšnem goriškem listu objavljeni. Tudi bi Vam bili hvaležni za obvestilo ali živi še kdo izmed njenih bližnjih sorodnikov, ki bi nam mogel nuditi te informacije, če ni tiskanih podatkov.

Zahvaljujemo se Vam že vnaprej za sleherno pomoč oz. nasvet v tej zadevi.

S tovariškimi pozdravi!

\author{
Ravnatelj: \\ Dr. Karel Dobida«
}

»Študijska knjižnica Nova Gorica

Solkan, 13. 3.58

Št. $133 / 58$

Predmet: Melita Rojic, Narodna galerija

slikarica - biog. podatki Ljubljana

V zvezi z Vašim dopisom z dne 27. februarja 58 štev. 79/1 ste nas zaprosili za podatke Melite Rojic, slikarice iz Gorice.

V Gorici (Italiji) smo zvedeli, da še živi njena sestrična Pavla Makuc, učiteljica, Gorizia, Via Trento 16, Italija.

Kolikor nam je znano je o Rojčevi poročal »Ženski svet« leta 1926. štev. 4.

Za vse ostalo se obrnite na gori omenjeno.

Upravnik: (Bidovec Ivan)« 


\section{Priloga 3 (Arhiv Narodne galerije)}

Ljubljana, dne 17. marca 1958

Štev. 79/2

Spoštovana gospa!

Za Slovenski biografski leksikon potrebujemo življenjske podatke o pok. slikarici Meliti Rojic, rojeni in umrli v Gorici, pa jih doslej žal nismo mogli nikjer dobiti. Izvedeli smo, da je bila pok. umetnica Vaša sestrična. Zato si dovolimo prav vljudno prositi Vas, da nam pošljete čimveč in čimbolj točnih podatkov o pokojnici. Potrebujemo predvsem:

1) datum rojstva in smrti;

2) glavne podatke o njenih starših;

3) kje se je učila slikanja, pri kom in kdaj;

4) poglavitne razstave, katerih se je udeležila;

5) kje se nahajajo njena dela; pripisano s svinčnikom in podatke;

6) ali je o njej razen »Ženskega sveta«, štev 4, letnik 1926, še kak drug list kaj več poročal. (s svinčnikom dodano morda ob kaki rojstni ali ob njeni smrti)

Če morda veste še kake druge podatke o njej, bi Vam bili zanje prav tako hvaležni.

Sprejmite, spoštovana gospa, za Vaš trud in ljubeznivost že v naprej našo iskreno zahvalo.

Z izrazi posebnega spoštovanja!

Gospa

Pavla Makuc, učiteljica

Gorizia, Via Trento 16

Italia

V Ljubljani, dne 14. maja 1958

Št. $79 / 3$
Ravnatelj:

Dr. Karel Dobida 
Spoštovana gospa!

Približno pred dvema mesecema smo Vam poslali pismo, čigar prepis prilagam. V njem smo Vas prosili za biografske podatke o pok. slikarici Meliti Rojic, Vaši pokojni sestrični.

Ker do danes nismo prejeli odgovora in se bojimo, da našega pisma niste prejeli, Vam pošiljamo ta dopis z vljudno prošnjo, da nam sporočite podatke, za katere smo Vas prosili. Če Vam to ni mogoče, bi nam storili veliko uslugo, ako nam morate sporočiti, kdo kaj več ve o življenju in delovanju navedene umetnice.

Že v naprej se Vam za uslugo lepo zahvaljujemo in ostajamo z izrazi resničnega spoštovanja!

Dr. Karel Dobida

Gospa Pavla Makuc, Gorizia, Via Trento 16, Italia 


\section{Priloga 4 (Arhiv Narodne galerije)}

\section{Št. $79 / 5$}

Spoštovana gospa!

Vaše prijazno pismo s konca meseca maja, s katerim ste mi tako ljubeznivo sporočili različne podatke o Vaši pok. sestrični, slikarici Meliti Rojic, sem prejel in se Vam za vso Vašo pozornost najlepše zahvaljujem.

Medtem sem prejel od g. Alojzija Lisjaka iz Renč 11 razglednic z reprodukcijami po delih Melite Rojčeve, katere ste mi poslali Vi. Tudi za razglednice se Vam prav vljudno zahvaljujem. Shranili jih bomo v arhivu Narodne galerije kot majhen prispevek $\mathrm{k}$ poznavanju dela navedene umetnice.

Zelo bi Vam bil hvaležen, spoštovana gospa, če bi mogli sporočiti še rojstni in smrtni datum Vaše pok. sestrične, ker brez teh osnovnih podatkov ne bi bilo mogoče uvrstiti njenega življenjepisa v Slov. biografski leksikon. Ker gredo imena z začetno črko »R« že v kratkem v tiskarno, je stvar nujna, sicer bi morala biografija M. Rojčeve izostati.

Zahvaljujem se Vam vnovič za vso dosedanjo prizadevnost in ljubeznivost in se Vam priporočam še vnaprej.

$\mathrm{Z}$ zagotovilom posebnega spoštovanja

ostajam K. Dobida

Velecenjeni g. ravnatelj! (rokopis)

Srčno me veseli, da sem Vam kolikor je bilo v moji moči ugodila. Hudo je gledati kako se naš človek pogreza v tuje vode. Morda bo pogled na naše nekdanje talente naše ljudi ohrabrilo, da ne utonejo. Čestitam graditeljem »Leksikona«. Rojic Melita rojena 6. V. $1879 \mathrm{v}$ Gorici in umrla 11. VIII. 1924 istotam.

Gorica 15. VI. 58

Nebroj voščil in pozdravov

Makuc Pavla 


\section{Priloga 5 (Fond D, Narodna galerija, Pismo Saše Šantla eni izmed sester)}

Dunaj, 3. dec. 1903

Ljubi srček!

Zakaj tako malo pišem? To vprašanje bi bilo naravnost naivno, ako bi ga redno stavil, ki pozna moje razmere. In ti jih poznaš. Vsaj mislim, da jih poznaš. Ali si moraš misliti sito, ki ima vse luknje zamašene $\mathrm{z}$ nesnago, tako da ni mogoče spustiti nobene tekočine skozi luknjice. To sito je podobno času, ki mi je na razpolago. Stalni urnik je mreža, ki se ne da spremeniti; luknjice, to so kratki presledki med urami, v katerih sem stalno okupiran, te luknjice so vse polne drugih opravil. Lahko ti bo zdaj razumeti, da ni mogoče spustiti skozi tako sito še pismo - to je tekočino, in da je treba siloma narediti kako luknjo, če se hoče to doseči. To luknjo sem danes naredil. Izostal sem danes iz ateljeja. Tema je taka, da še sedaj ob 10. uri pišem pri luči, ki brli nejevoljno poleg mene, ker ni vajena tega nenavadnega opravila. Akt sem včeraj doskiciral. Popoldne mi namreč danes tudi ni mogoče iti v atelier. Jutri bom napravil še nekaj. - No to te ne bo mnogo zanimalo. Iz atelijeja poročam že tako še precej redko. Poleg mene leži zopet kup novih barv, ki bodo jutri vandrale na »Lovrensko goro«. Kaj imam dopoldne vprašaš? O to te gotovo zanima. Vsi jugoslovanski dijaki v zvezi s severnimi brati, Čehi, Poljaki, Rusini itd. se bomo zbrali v znani dvorani »Ressource«. Mož pri možu bo stal ko bodemo poslušali govore, $\mathrm{v}$ katerih se nam bodejo slikale bojah krivice, ki se gode našemu ubogemu slovenskemu narodu. Vztrepetalo bo marsikatero srce iz svetle jeze a src potrtih ne pojdemo domov. Ne verjamem, da bi ne dali duška svojemu ogorčenju. Saj veš, kako delajo dijaki. Če nas je okoli tisoč se celega Dunaja ne bojimo. Kako so se stotine nemških puršev v raznobarvnih a' cfaicah (?, op. L. T.) umaknile prejšnjo soboto iz polnonatlačene univerze. Šele ko so bili vsi zunaj, smo šli še mi za njimi ven. Potem pa nisem bil zraven pri demonstracijah pred Parlamentom itd., ker je vladal precejšnji nered v »bojnih četah « in ker je bila ura 3/4 1 moj želodec pa je imel neko silno poželenje po naši menzi... No radoveden sem kaj bo danes. Gotovo se bo pesem »Hej Slovan!« razlegala po dunajskih ulicah. A v strahu ni treba biti nikakor. To pravim, ker vem, da imate o takih stvareh krive nazore. Kdor pazi temu se nič ne zgodi. »Vesna« se seveda oficijalno ne udeleži. Prvič, ker ni »akademično« društvo, drugič ker to nikakor ne spada v njen delokrog. Toliko, da ne bodete videli kake nevarnosti, katero je papa čital v časnikih, da je rektor univerze zagrozil, da bo dal predsednike vseh akademskih društev zapreti ako ne bo miru. Seve se to »Vesne« ne tiče. Toliko v pojasnilo. Ker sem že omenil »Vesno« naj povem še kako. Včeraj je bil III. obč. zbor, ki je bil skoro polnoštevilno obiskan. Še nikdar ni bilo tako zanimivo kakor včeraj. Najzanimivejša je bila predzadnja točka dnevnega reda, poročilo jury-ja za razglednice 
in razdelitev nagrad. Do takrat ni imel nihče pojma, kako je stvar izpadla. In glej srečo, I. nagrada je doletela mene. Dobil sem $20 \mathrm{~K}$, katere sem pa seveda dal »Vesni«, ker bi ne bilo lepo, če bi jo oropal teh par kronic. Sicer bi jih bil lahko dobro potreboval, a kaj se hoče... II. nagrado je dobil Gaspari. Njegova razglednica »bel predpasnik« vam bo gotovo jako ugajala. V celem je sprejetih 6 razglednic. Upam, da bodo napravile mnogo efekta. To veste menda da predstavlja moja »regiment po cesti gre«. Včeraj smo si zbrali tudi končno znak (?, op. L. T.). Pravila že imamo, a nimamo še vseh naročenih odtisov. Zato jih podpornikom še ne moremo poslati. - Da gremo Fickutovci v soboto v Dürrenstein, to menda veste že. Mislim, da sem o tem že pisal, ker je to že davno sklenjeno. Pri tej priliki si ne morem kaj, da bi ne omenil, da mi za to rajžo ne bo ostalo dovolj cvenka in da bi vrlo rad imel do takrat kaj podobnega v levem hlačnem žepu. Prosim apeluj, če si tako prijazna na višje inštance. Svirali bomo med drugim Bruknerjev prekrasni kvintet (2 gosli, 2 vijoli in čelo). Z nami se vozi Ruda in če bo vreme lepo tudi njegova sestra. No kaj bi te še zanimalo? Res, v četrtek, 10 grudna, sem povabljen zopet $\mathrm{k}$ Hassu, K sauperju. Povabljeni so sami muzikalični gostje, med drugimi bodoči operni pevec Dr. Nafdolović, znana klavirska virtuozinja Vera Schapira., ki je pred kratkim koncertirala v Bösendarferjevi dvorani, gdč. Ruda in drugi. Svirali bomo tudi en kvartet (Beethoven op. 18. št. 2 (op. L. T.)). Dr. Nafdolović bode pel dve moji pesmi (!), ki sem jih posvetil Rudi (Tako so mi pravili včeraj.) No, das (? L. T.) kam sem vreden. -

Glede vojaščine sem se natančno informiral pri profesorju (?, nečitljivo, op. L. T.) in sekretarju. Štipendije med vojaškim letom nikakor ne morem dobiti. Pač pa riskiram, da jo še za četrto ateljejsko leto zgubim, če pretrgam študije. Tako je pri nas! Odložim pa lahko vojaško leto tudi dve leti ali še več po študijah, tako da napravim prej duj (?, op. L. T.) izpit., kar hočem na vsak način. Torej k naboru pojdem v Gorici. Ali ne pozna papa nobenega voj. zdravnika? Vsaj oni hrv. (?, op. L. T.) stotnik bi lahko komu kaj rekel. Vredno bi bilo napravite korake radi tega. Če me dvakrat spustijo, moram služiti le 8 tednov in ne izgubim leta. No o tem bomo še govorili o božiču. Pridem najbrže že 19. zjutraj v Gorico. Tak pa z Bogom ljubček moj, ne uči se preveč tvoj Saša (na robu pisma) Pozdravi mi vse naše. Rad bi videl zopet kako pisanje od doma. 


\section{Bibliografija}

\section{Viri}

Arhiv Narodne galerije, 27. februar 1958, št. 79/1; Študijska knjižnica Nova Gorica, Solkan, 13. marec 1958, št. 133/58.

Arhiv Narodne galerije, 17. marec 1958, št. 79/2; 14. maj 1958, št. 79/3.

Arhiv Narodne galerije, Gorica, 15. junij 1958, št. 79/5.

Narodna galerija, Fond D, Šantel, Pismo Saše Šantla eni izmed sester, Dunaj, 3. december 1903.

Narodna in univerzitetna knjižnica, Rokopisna zbirka in zbirka redkih tiskov, Melita Rojic, MS 1492, mapa 82 (7, 1913-1914).

\section{Literatura}

A. H. O., Prva slovenska umetniška razstava v Trstu in misli ob njej, Ljubljanski zvon 27 (7), 1907, str. 761-763.

A. A. [Aškerc, A.], II. slovenska umetniška razstava v Ljubljani, Ljubljanski zvon, 1902, str. 714-715.

Artist, Jugoslovanska umetniška razstava v Sofiji (Sredcu), Slovan 1906/1907, str. $51-54$.

Dobida, K., pod geslom: Rojic Melita, Slovenski biografski leksikon, 3/IX, Ljubljana 1960, str. 125-126.

Dolinar, D., Ilešič, F., Enciklopedija Slovenije, IV, Ljubljana 1990, str. 105.

Delneri, A., Sgubin, R., Secessione ed esotismo. L'avventura artistica di Edoardo Del Neri, 10. dicembre 2004-31. marzo 2005, Musei Provinciali, Gorica 2005.

Felc, V., Odprli so grajski park z Zoisovo uro, Bohinjske novice 9/8, 4. avgust 2006,http:// obcina.bohinj.si/index.php?id=149\&no_drblob_pi1\%5BdownloadUid\%5D=43 [12. 9. 2012].

FK, Spomin na Del Nerija, Primorske novice, 9. junij 2012, http://www.primorske.si/ Kultura/Spomin-na-Del-Nerija.aspx [4. 3. 2013].

Grafike, pasteli, risbe in akvareli starejših primorskih slikarjev, 26. junij 1981-15. julij 1981, Galerija Rika Debenjaka, Kanal ob Soči 1981.

Ilustrirani katalog medjunarodne grafičke izložbe Hrvatskog društva umjetnosti, februar 1914, Zagreb 1914.

Kaj vse pravijo!, Soča 27 (17), 23. april 1897, str. 1. 
Katalog izložbenih umetničkih dela na I. jugoslovenskoj umjetničkoj izložbi. U Beogradu, Beograd 1904.

Katalog prve slovenske umetniške razstave v Trstu, 1907, Trst 1907.

Komelj, M., Katalog razstavljenih del, v: Ivan Vavpotič. 1877-1943, Narodna galerija, Ljubljana 1987, str. 79-101.

Komelj, M., Zlati vek razglednic, v: Slovenska kronika XIX. stoletja. 1884-1899 (ur. Cvirn, J.), Ljubljana 2003, str. 321-322.

Koršič, V., K odkrivanju goriške slikarke Melite Rojic. Ob stoletnici rojstva 1879-1979, Goriški letnik 6, 1979, str. 333-336.

Koršič, V., pod geslom: Rojic Melita Marija Ana Vincencija, Primorski slovenski biografski leksikon, XIII, Gorica 1987, str. 220-221.

Koršič Zorn, V., L'arte dall'Ottocento al primo Novecento, v: Cultura slovena nel Goriziano, Gorica 2005, str. 141-163.

Koršič Zorn, V., Zametki moderne umetnosti med Slovenci na Goriškem, v: Umetnost 20. stoletja na Goriškem in v Posočju (ur. Vuk, M.), Gorica 2000, str. $11-44$.

Lampe, E., Druga umetniška razstava, Dom in svet 15, 1902, str. 694-695.

Malni Pascoletti, M., pod geslom: Del Neri, Edoardo, Dizionario Biografico degli Italiani, XXXVIII, 1990, http://www.treccani.it/encislopedia/edoardo-del-neri_ (Dizionario-Biografico) [19. 2. 2013].

Martelli, C. H., Dizionario degli artisti di Trieste, dell' Isontio, dell' Istria e della Dalmazia, Trst 2001.

Marušič, B., Gorizia xe sciava, v: Slovenska kronika XIX. stoletja. 1884-1899 (ur. Cvirn, J.), Ljubljana 2003, str. 272-273.

Melita Rojic, Goriška straža 7 (63), 14. avgust 1924, str. 4.

Menaše, L., pod geslom: Rojic, Melita, Svetovni biografski leksikon, Ljubljana 1994, str. 824.

Merhar, I., Prva slovenska umetniška razstava v Trstu, Ljubljanski zvon 27 (11), 1907, str. 697.

Mikuž, S., Maksim Gaspari, Ljubljana 1978.

Pregl, T., Slovenska knjižna ilustracija. Ob razstavi Slovenska knjižna ilustracija 1979/1980, Ljubljana 1979.

Prva slovenska umetniška razstava v Trstu, Slovenec 35 (246), 24. oktober 1907, str. 1.

Regali - Sever, J., Prva jugoslovanska umetniška izložba v Belgradu, Ljubljanski zvon 24 (11), 1904, str. 686-746. 
Rehar Sancin, L., Pomembne, a nam nepoznane Tržačanke in Goričanke. Melita Rojic (slikarka, 1879-1924), Primorski dnevnik, 18. maj 2008, str. 18.

Schmidt-Liebich, J., Lexikon der Künstlerinnen 1700-1900. Deutschland, Österreich, Schweiz, München 2005.

Schweiger, W. J., Vereinigung Österreichischer Bildender Künstler und Künstlerinnen, 2003, www.onb.ac.at/ariadne/vfb/bt_fk_voebkk.htm [30. 8. 2012].

Seznam II. slovenske umetniške razstave. 1902, Ljubljana 1902.

Simonišek, R., Slovenska secesija, Ljubljana 2011.

Slovenska žena (ur. Govekar, M.), Ljubljana 1926.

Slovenska umetniška razstava v Trstu, Dom in svet 20 (11), 1907, str. 527.

Smrekar, A., Karel Dobida. 1896-1964. Publicist, prevajalec, direktor Narodne galerije. Ob 110. obletnici rojstva, 14. marec-7. maj 2006, Narodna galerija, Ljubljana 2006.

Stelè, F., Umetnost v Primorju, Ljubljana 1960.

Šantel, S., Med barvami in glasbo, v: Šantel st., A., Šantel ml., A., Šantel, S., Življenje v lepi sobi, Ljubljana 2006, str. 131-211.

Šantel, S., Spomini na dunajsko šolanje, Umetnost 6 (20), 1941/1942, str. 92-100.

Šlebinger, J., pod geslom: Ilešič Fran, Slovenski biografski leksikon, 1/III, Ljubljana 1928, str. 360-361.

[Umetnostna priloga], Savremenik 9 (7), 1914, sl. [421].

Umetnostna priloga, Slovan 5, 1906/1907; 7, 1909; 10, 1912, str. [113, 177, 289, 320321]; 11, 1913, str. 281, 355; 13, 1915, str. 156.

Vidmar, R., Obrazi in duše, Ženski svet 4, 1926, str. 7-98.

Vojanov, II. slovenska umetniška razstava v Ljubljani, Ljubljanski zvon 22 (12), 1902, str. 787-789.

Vrišer, V., pod geslom: Trnski, Ivan, Enciklopedija Jugoslavije, VIII, Zagreb 1971, str. 371.

Vuk, M., Duhovnija Dornberk. 700 let [Dornberk 1995].

Žerovc, B., Vesna ob izviru umetnosti, v: Potlačena umetnost. Zbornik (ur. Borčić, B., Mikuž, J.), Ljubljana 1999, str. 50-77. 


\section{Lidija Tavčar \\ Razglednice Melite Rojic $v$ arhivu Narodne galerije}

Ključne besede: likovne ustvarjalke, akademsko društvo Vesna, biografija, akvarel, razglednice, korespondenca, slovanofilstvo, etnološka kulturna dediščina

Do sedaj pisci o Goričanki Meliti Rojic (1879-1924) niso izpostavljali dejstva, da je bila članica Vesne, $v$ članku pa poskušamo pokazati, da je slikarka posvojila naloge društva, kar je posredno vplivalo na izbiro njenih »etnoloških « motivov. Še več, uresničila je pomembno društveno zahtevo po izdajanju razgledniških motivov. Ob tem v prispevku opozarjam na do sedaj neobjavljeno korespondenco med slikarko in urednikom Slovana Franom Ilešičem, kjer se je v rokopisu med drugim ohranil tudi njen življenjepis. Tega pa ni poznal Karel Dobida (1896-1964), ravnatelj Narodne galerije, zato si je po drugi svetovni vojni, ko je Gorica pripadla Italiji, dopisoval s slikarkino sestrično, $\mathrm{z}$ namenom pridobiti njene življenjske podatke za sestavo leksikalnega gesla. Tako je prvič objavljena korespondenca med njim in Pavlo Makuc, ki mu je tudi posredovala enajst natisnjenih razglednic, katerih avtorica je bila M. Rojic. Ti razgledniški krajinski motivi imajo nedvomno dokumentarno vrednost. Poleg tega tovrstne upodobitve krajev pomenijo nadaljevanje nekdanjega vedutnega slikarstva, saj sodobnikom pogosto edine izpričujejo nekdanjo podobo slovenskih krajev, ne le panoram, marveč tudi posameznih ožjih predelov. 


\section{Lidija Tavčar \\ Melita Rojic's Postcards in the National Gallery's Archives}

Keywords: women artists, the academic society Vesna, biography, watercolour, postcards, correspondence, Slavophilia, ethnological cultural heritage

Until now it has not yet been emphasized that Melita Rojic (1879-1924), a woman from Gorica, was a member of the academic society Vesna. This article is an attempt to show that the painter internalized the tasks of the society and that this indirectly influenced her choice of her "ethnological" motifs. What is more, she fulfilled an important requirement of the society: publishing postcard motifs. The article also focuses on the as-yet-unpublished correspondence between the painter and the editor of Slovan, Fran Ilešič, a correspondence that contains a preserved handwritten biography of Rojic. After the Second World War Gorica became a part of Italy and, not being familiar with the biography of Rojic, National Gallery Director Karel Dobida (1896-1964) corresponded with the painter's cousin to acquire information about her life in order to compile a lexicon headword. For the first time, the article reveals the correspondence between Dobida and Pavla Makuc, who passed on to him eleven printed postcards by Rojic. The landscape motifs undoubtedly display a documentary value. This type of site depiction also represents a continuation of the former vedute painting; moreover, contemporaries consider them to be the only witness of former views of Slovenian sites - not only panoramas but also views of individual specific areas. 